\title{
港内静稂度に及ぼす防波施設の反射·透過波の 周期特性の影響について \\ INFLUENCE OF TRANSMISSION AND REFLECTION PROPERTIES OF MARITIME STRUCTURES WITH WAVE PERIOD ON A HARBOR TRANQUILITY
}

\author{
中村孝幸 $1 \cdot$ 村上浩司 ${ }^{2} \cdot$ 国本栄一 3 \\ Takayuki NAKAMURA, Kouji MURAKAMI and Eiichi KUNIMOTO \\ 1正会員 工博 愛媛大学助教授 工学部環境建設工学科（テ790-8577 松山市文京町3番） \\ 2 正会員 侏芙蓉調查設計事務所（广790-8022 松山市美沢1丁目2-30） \\ 3 正会員 三省水工㑣）松山支店（テ790-0011 松山市千舟町5丁目5番3号）
}

\begin{abstract}
Recently, it has become known that multi directional and irregular natures of incident waves are important for estimating wave sheltering effects by maritime structures, such as wave diffraction effects about a harbor entrance gap. In this study, concerning with variations of wave reflections and transmissions about harbor breakwaters with wave period, the harbor tranquility for the incidence of multi-directional and irregular waves was examined extensively. The vertical line source Green's function method was basically used for the numerical computations. Extension of the method to the permeable boundary conditions was briefly introduced.
\end{abstract}

Key Words: Harbor tranquility, multi-directional and irregular wave, variation of wave reflection and transmission, permeable breakwater

\section{1. まえがき}

現在, 港内の波浪静噯度の検討は, 来襲波の多方向性 および不規則性を採り入れた方法に基づき行われてきて いる 期（あるいは波長）に強く依存するため, 有義波など代 表波を規則波に置き換えて港内波浪の算定を行うと回 折・屈折変形が十分に再現できないことや特に反射現象 による部分重複波の腹・節の位置があまりにも強調され 過ぎるなど現況と異なることによる。

現在，港湾域では各種の防波施設が用いられるように なってきており, その中には, 浮防波堤や直立式消波構 造物など，作用波の周期による反射・透過率の変動が有 意なものも数多く見られる. しかしながら, 現状の港内 波浪静榣度の算定では，旧来方式の有義波など代表波を 規則波に置き換え，それに対する反射・透過率を利用す
ることが多い，近年では，不規則波実験を実施して，代 表波に対する反射・透過率を求め，それを利用すること も行われるようになっているが，一定值の透過・反射率 を用いることに変わりはない.

いずれの方式を採るにしても，回折・屈折変形は複数 の成分波を対象にして行うの対して，反射・透過現象は 代表波に対して行うなど方法論が統一されていないこと が指摘できる。

ここでは，防波施設による反射・透過現象についても， 波の回折・屈折現象と同様に波周期による変動特性を採 り入れる方法論を展開する．そして，特に作用波の周期 による反射・透過率の変動が有意な, 浮体式防波堤を例 にとり，旧来方式と新方式による算定を行い，港内静稳 度に及ぼす反射・透過現象の周期特性の影響について明 らかにする。 


\section{2. 鉛直線グリーン関数法に基づく数值解析法}

以下の理論的な検討では，既に著者らの中の一人²)が 展開している，鉛直線グリーン関数法に基づく港湾域の 波高分布の算定法を用いており，その概要について紹介 する.このとき, 従来の解析で不明確なままとなってい た点や本研究で主対象とする周期による反射・透過波特 性の変化の取り扱い方法なども合わせて記述する.

\section{（1）規則波（成分波）に対する算定法}

本研究では, 各種の周期の正弦波が各方向へ伝播する 状態を線形的に重ね合わすことで，現地の多方向不規則 波が表現できると仮定する.そして，このような表現に よる多方向不規則波が港湾域に来襲するとき, 波高分布 等を知るためには，まず最初に多方向不規則波を構成す る成分波に対する結果を求めておく必要がある．すなお ち，任意周期で，任意方向より作用する規則波に対する 港湾域の波高分布の算定が必要とされる.

図一 1は，このような規則波（波高 $\mathrm{H}$, 周期 $\mathrm{T}$, 波向 き $\theta$ ） が作用するときの港湾域の算定モデルを示す．港 湾域は，不透過な陸域境界や島堤で構成され，島堤の中 の一つあるいは陸域の一部は透過性堤体とする . 図中で は, 陸域の境界線を $C_{L}$, 透過堤の周辺境界線を $C_{P}$ とし てある. そして，これら不透過および透過境界の特性は， 鉛直断面内の 2 次元実験や理論解析による反射率 $\mathrm{Cr}$ お よび透過率C t で表されるとする.

平面波が図一 1 のような一定水深内の港湾域 に作用す るとき，考慮すべき現象は波と構造物との干涉に起因す る回折散乱と反射・透過現象になる. 従来, このような 場での波の回折散乱と反射・透過現象は，ポテンシャル 波動論に基づき検討されている．いま，入射波と回折散 乱波の速度ポテンシャルをそれぞれ $\Phi_{I}, \Phi_{S}$ とすると， その基礎方程式は, 次式で示す 3 次元のラプラス方程式 を満足する。

$$
\frac{\partial^{2} \Phi_{j}}{\partial x^{2}}+\frac{\partial^{2} \Phi_{j}}{\partial y^{2}}+\frac{\partial^{2} \Phi_{j}}{\partial z^{2}}=0 \quad(j=I, S)
$$

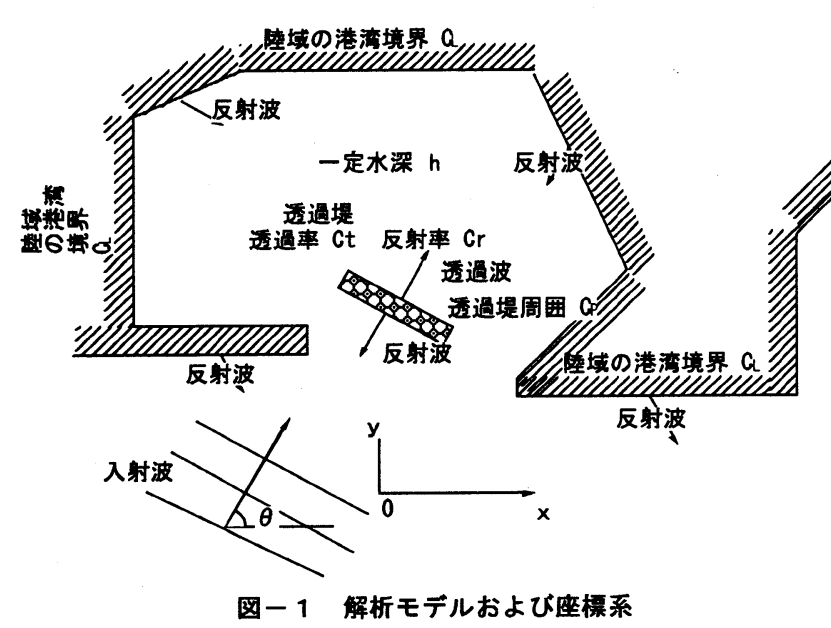

ここに, $(\mathrm{x}, \mathrm{y})$ は平面直交座標系を， $\mathrm{z}$ は原点を水表面 に置き，鉛直上方を正とする鉛直座標である．このとき， 回折散乱波の速度ポテンシャルには，反射・透過波の影 響も含まれている。

線形波動理論を仮定すると，末知量である回折散乱波 の速度ポテンシャル $\Phi_{S}$ は，一定水深であることおよび 周辺境界が鉛直面であることを考慮すると，次式で示す ような進行波モードの解を仮定できる.

$$
\Phi_{S}(x, y, z ; t)=\varphi_{S}(x, y) \frac{\cosh \{k(h+z)\}}{\cosh (k h)} \exp (-i \omega t)
$$

ここに, $\varphi_{S}$ :回折散乱波の速度ポテンシャルの複素振幅， $\mathrm{h}$ :水深, $\omega$ :角振動数 $(=2 \pi / T, T$ : 周期 $), i$ :虚数, $\mathbf{k}$ : 進 行波モードの波数で次式の分散関係式を解いて与えられ る.

$$
\omega^{2}=g k \tanh (k h)
$$

ここに, $\mathrm{g}:$ 重力加速度である.

入射波として, その水面変動 $\eta_{I}$ が次式で与えられるも のを仮定する。

$$
\begin{gathered}
\eta_{I}(x, y)=\frac{H}{2} \cos \left(k_{x} x+k_{y} y-\omega t\right) \\
\Phi_{I}(x, y)=-\frac{i g H}{2 \omega} \frac{\cosh \{k(h+z)\}}{\cosh (k h)} e^{i\left(k_{x} x+k_{y} y-\omega t\right)} \\
=\varphi_{I}(x, y) \frac{\cosh \{k(h+z)\}}{\cosh (k h)} e^{-i \omega t}
\end{gathered}
$$

ここに, $\mathrm{H}$ : 入射波高, $k_{x}=k \cos \theta, k_{y}=k \sin \theta, \theta$ :波の 入射方向とx軸とのなす角.

このとき, 入射波の速度ポテンシャル $\Phi_{I}$ は次式のよ うに定義できる。

ここに， $\varphi_{I}$ は入射波の速度ポテンシャルの複素振幅に相 当する.

式（2）を式（3）に代入すると，この解析での基礎 方程式で, 平面座標にのみ依存するへルムホルツ方程式 一と導加る。

$$
\frac{\partial^{2} \varphi_{S}}{\partial x^{2}}+\frac{\partial^{2} \varphi_{S}}{\partial y^{2}}+k^{2} \varphi_{S}=0
$$

鉛直線グリーン関数法では，へルムホルツ方程式の特 異解で円筒波を表す鉛直線グリーン関数を基磷解とする もので, これは次式で示される31. 


$$
G(x, y ; X, Y)=-\frac{i \pi}{4} H_{0}^{(1)}(k R)
$$

$$
R=\sqrt{(x-X)^{2}+(y-Y)^{2}}
$$

ここに, $H_{0}^{(1)}(k R): 0$ 次の第 1 種ハンケル関数で, 引 数のRは一般点 $(x, y)$ と湧出し点 $(X, Y)$ との間の平面距離 で式 ( 8 ) による.

鉛直線グリーン関数法では, 式 ( 7 ) で示される円筒 波型の解を港湾周辺境界に密に分布させて, 防波堤など の不透過条件や低反射条件をより厳密に満足させるよう に波源強度を決定した後に波高分布を求めている。

このような解析によると, 回折散乱波の速度ポテン シャルの振幅 $\mathrm{s}$ は, 上記の鉛直線グリーン関数 $\mathrm{G}(\mathrm{x}, \mathrm{y} ; \mathrm{X}, \mathrm{Y})$ を用いると涌き出し分布法を介して次式のよ うに表すことができる゙）。

$$
{ }_{s}(x, y)=\int_{C_{P}+C_{L}} f_{S}(X, Y) G(x, y ; X, Y) d C(X, ;
$$

ここに, $C_{P}+C_{L}(=C)$ は島堤を含む港湾境界に沿う曲線 を示し, その曲線上の座標点が $(X, Y)$ で, 涌出し関数で あるグリーン関数 $G(x, y ; X, Y)$ の置かれる位置である. $f_{S}(X, Y)$ は, その涌出しの強さを示し, 港湾境界上の反 射特性や透過特性を考慮して決定できる。

a ）港湾境界を不透過条件とするときの回折散乱波

ここでは, 港湾境界が全て不透過なものとして, 回折 散乱・反射現象に着目して, 回折散乱波の速度ポテン シャルを求める．ここでは，反射特性を表すのに部分吸 収条件が適用できるものとしており，このような吸収条 件を用いると，反射特性を考慮した港湾境界上での境界 条件は次式で与えられる21.

$$
\begin{aligned}
& \int_{c} f_{S}(X, Y)\left\{i k \alpha(x, y) G(x, y ; X, Y)+\frac{\partial G(x, y ; X, Y)}{\partial n}\right\} d c \\
& =-\left\{i k \alpha(x, y) \varphi_{I}(x, y)+\frac{\partial \varphi_{I}}{\partial n}\right\} \mid \begin{array}{c}
(x, y) \text { on } c
\end{array}
\end{aligned}
$$

$$
\alpha(x, y)=\frac{1-C_{r}(x, y) e^{i \delta(x, y)}}{1+C_{r}(x, y) e^{i \delta(x, y)}}
$$

ここに， $\partial / \partial n$ : 構造物の没水面上での法線微 分, $\alpha(x, y)$ : 吸収率, $C_{r}(x, y)$ : 港湾境界 $(x, y)$ おける反 射率, $\delta(x, y)$ : 反射波の遅れの位相角で, 鉛直不透過面 よりの完全反射時における反射波よりの遅れを表す. 式 $\left(\begin{array}{ll}1 & 0\end{array}\right)$ は $f_{S}(X, Y)$ を末知数とする 1 次元の積分方程
式になっており，これを解くことにより湧き出し強さが 求められる.このように，式(10)を解くことにより湧 出し強さが，さらにこれを式(9)に代入することにより， 回折散乱波の速度ポテンシャルの複素振幅が算定できる。

平面波浪場の任意点 $(x, y)$ における回折係数 $K_{D}(x, y)$ は， 上記のようにして求められた回折散乱波の速度ポテン シャルを用いて次式により算定できる.

$$
K_{D}(x, y)=\frac{\left|\varphi_{I}(x, y)+\varphi_{S}(x, y)\right|}{\left|\varphi_{I}(x, y)\right|}
$$

\section{b ）透過堤の近似的な取り扱い}

ここでは, 従来の研究 ${ }^{2)}$ と同様に, 基本的には港湾境 界が不透過条件のときの算定結果を利用して，この結果 に透過堤よりの透過波の影響を線形的に重ね合わせると いう近似的な取り扱いにより，透過堤を含む港湾域の波 高分布の算定を行う.

このような方法での算定ステップは次のようにまとめ られる。

ステップ(1) : 透過堤を不透過堤とみなし，港湾域内で の反射波の算定を行う。この算定は，上記で紹介した諸 式を用いて実行できる.

ステップ(2) : 入射波と(1)での反射波を併せて，透過堤 に作用させ，透過波の算定を行う。このとき，透過堤自 身よりの反射波の影響は考慮しない。

従来の研究 2)では, このステップにおいて堤体の透過 面と入射波および反射波の波向きの関保が不明確なまま となっていた. 本研究ではこの点について詳細な検討を 行い，結論的に図一 2 に示すように，入射波の場合には， 入射波の波向きべクトルと透過堤境界上に立てた外向き 法線べクトルとが同方向となる場合のみ, また周辺境界 よりの反射波が透過堤に入射する場合, 着目する反射源

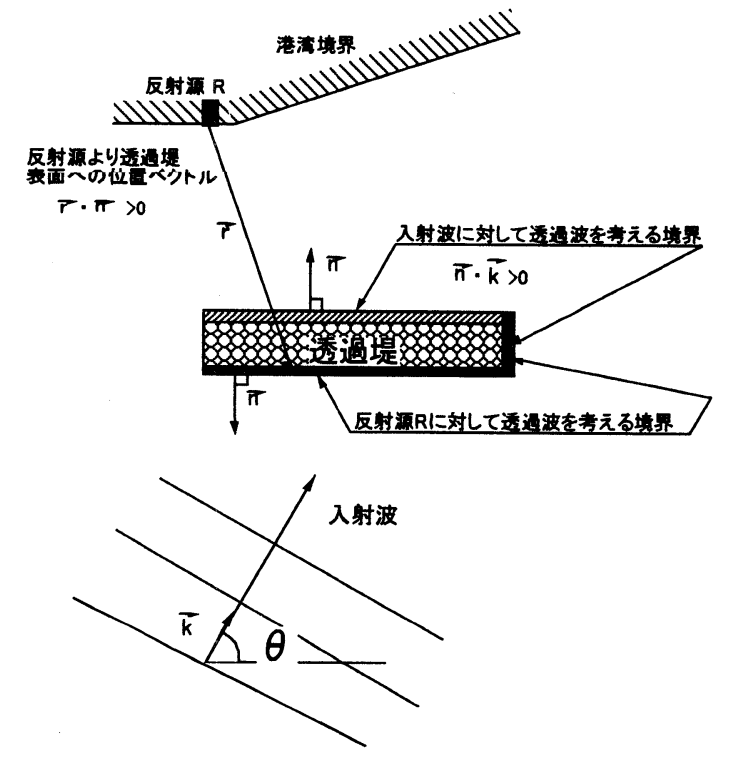

図-2 入射源からの波向きにより透過波を 考える境界の設定法 
より透過堤境界へ伸びる位置ベクトルとやはり同様の外 向き法線ベクトルとが同方向になる場合のみ, 着目する 透過堤境界より透過波が抜けるようにする必要があるこ とが確認されている.

ステップ(3): 透過堤よりの透過波を入力として, 港湾 域全体よりの反射波を算定する。このとき，透過堤自身 よりの再反射波の影響も考慮する。

ステップ(4): 透過堤に, (3)で算定された反射波を再度 作用させて透過波の算定を行う。このとき，透過堤自身 よりの反射波の影響は考虑しない.

ステップ(5) : 透過堤を透過する波あるいはその反射波 が十分に小さくなるまで(3)，(4)のステップを繰り返し， 求められた各結果を線形的に重ね合わせることで最終的 な波高分布を求める．ただし，以下の算定では，収束性 が良かったことから，この繰り返しステップは 1 回のみ に限定しており, 違う機会に収束性等について詳細に検 討したい。

上記の各計算ステップに対応する算定式を示すと以下 のようである.

ステップ(2に対応する算定式 : 透過波の速度ポテンシャ ルの複素振幅 $\varphi_{T}$ は， $\varphi_{S}$ と同様に鉛直線グリーン関数を 核関数とする湧き出し分布法により表せるものとした.

$$
\varphi_{T}(x, y)=\int_{C_{P}} f_{T}(X, Y) G(x, y ; X, Y) d C(X, Y)
$$

ここに, $f_{T}$ は透過堤境界上に置く湧き出しの強さの分布 関数， $\mathrm{C}_{\mathrm{p}}$ はこの透過堤境界である.このとき, 透過堤は 有限厚さのものとしており, 面としての堤体堤の影響が 考虑できるようにしてある.

湧き出しの強さ $f_{T}$ は, ステップ(2)の説明の所で述べた ように, 入射波と周辺境界よりの反射波の影響を考慮し て次式により決定できる。

$$
\frac{\partial \varphi_{T}(x, y)}{\partial n}=\left\{i\left(k_{x} x+k_{y} y\right) \varphi_{I}(x, y)+\frac{\partial \varphi_{R}(x, y)}{\partial n}\right\} C_{t}(x, y) e^{i \delta_{T}}
$$

ここに， $C_{t}$ は透過率， $\delta_{T}$ は透過現象に伴う位相遅れの 角度である.ここで, 注意すべき事項として, 図一2で 説明した透過堤表面に対する波向きの影響がある。また， 着目している透過堤からの反射波は, 上式の右辺には考 虑しない.これは透過堤よりの透過波には，反射波は影 響しないことによる。

ステップ(3に対応する算定式 : 式 (1 14 ) を解くこと で, 式 $\left(\begin{array}{ll}1 & 3\end{array}\right)$ に含まれる湧き出し強さ $f_{T}$ が求まり, 結 果的に透過波速度ポテンシャルの複素振幅 $\varphi_{T}$ が港湾域 内の任意点に対して算定できる，そこで，透過波を源に
する港湾境界よりの反射波を求めることが可能になる. この算定は, 単に式 ( 10 ) の右辺の入射波ポテンシャ ルの振幅に代わり，式（１３）の透過波ポテンシャルの それを代入することで実行できる。

\section{（ 2 ）多方向不規則波の取り扱い}

合田 ${ }^{1)}$ は, 無数の周波数およひ波向き成分波の線形重 ね合わせにより，多方向不規則波が表現できるとする考 え方に基づき，防波堤による回折係数の推定法などを提 案している.また, 合田 ${ }^{1}$ は実際設計に便利なように, 不規則波のスペクトルの代表波表示による標準化やその 離散化手法も併せて示している.

ここでは，上記した算定法に基づき成分波に対する波 高比等を求め, さらに合田による多方向不規則波の取り 扱い方法を用いて，エネルギ一的な波高比等を最終的に 算定した。このエネルギー的な波高比 $\left(K_{D}\right)_{e f f}$ は, 次式 の定義による.

$$
\left(K_{D}\right)_{e f f}=\left[\frac{1}{m_{0}} \int_{0}^{\infty} \int_{\theta_{\min }}^{\theta_{\max }} P(f ; \theta) K_{D}{ }^{2}(f ; \theta) d \theta d f\right]^{1 / 2}
$$

ここに, $K_{D}(f, \theta)$ は周波数 $\mathrm{f}$, 波向 の成分波に対す る波高比, $\mathrm{m}_{0}$ は周波数方向スペクトル $P(f, \theta)$ の積分值, $\theta_{\text {max }}, \theta_{\text {min }}$ はそれぞれ方向角の最大・最小值で, 対象 海域に対して遮蔽物がないときには，波の主卓越方向よ り左右に $90^{\circ}$ の值が用いられる.

実際的な算定では, 式 ( 15 ) 中の周波数方向スペク トルを, 周波数および波向きの両者について有限個の区 間に分割して，各代表周期および各代表波向きのスペク トル成分をまず算出する。そして，これら成分波に対す る回折係数 $K_{D}$ を求めて, 離散化された式 $(15)$ によ り，有効回折係数 $\left(K_{D}\right)_{\text {eff }}$ 算定できることになる。

\section{（3）透過 - 反射率の周期による変化の取り扱い}

本研究では, 上記したような数值解析法に基づき, 多 方向不規則波を入力として, 港湾域の波高分布の算定を 行った.このとき，波周期による消波構造物の透過・反 射率の変化を考慮する方法として以下の 2 つの方法を採 用した。

a ）各周期成分波に対して個別の透過率 $C_{t}$, 反射率 $C_{r}$ を設定する方法

この方法は，不規則波を近似する有限個の周期成分波に 対して, 実験結果や数值算定結果を参照して, 個別に $C_{t}, C_{r}$ を設定する方法である. 算定では， $C_{t}, C_{r}$ の波 周期による変化が一般的な条件に対して与えられるよう に, 実験結果や数值算定結果を入力として 3 次スプライ ン補間法を適用して任意周期条件下で $C_{t}, C_{r}$ が推定で きるようにした。 
b ）エネルギー平均した透過・反射率を用いる方法

この方法は, やはり $C_{t}, C_{r}$ の実験結果や数値算定結 果を参照して，システム関数的に透過波および反射波の スペクトルを算定しておき，入力である入射波スペクト ルとの比の平方根をとることでエネルギー平均した透 過・反射率を求める. そして, この一定透過・反射率を 代表值として，港湾域の波高分布を算定する方法である。

\section{3. 港洼域の浮防波堤を対象にした算定結果}

\section{（1）港滩モデル}

ここでは，上記の解析法の妥当性を検証することおよ び透過・反射率の周期変化の影響を検討する目的から， 図一3に示すポンツーン形式の浮防波堤を想定して平面 波浪計算を実施した。 なお，図一3は，断面 2 次元実験 の様子を示すもので，現地量に換算して表示してある. 算定では, 図一 4 中に斜線で示す港湾の一部にこの浮防 波堤を設置した。この図中には, 浮防波堤以外の陸域境 界や島堤の反射率の值などについても併せて示した。

\section{（2）浮防波堤の透温 $\cdot$ 反射率}

図一5は，この浮防波堤の断面 2 次元実験による透過 率 $C_{t}$ と反射率 $C_{r}$ の結果および中村ら ${ }^{4)}$ の減衰波理論に
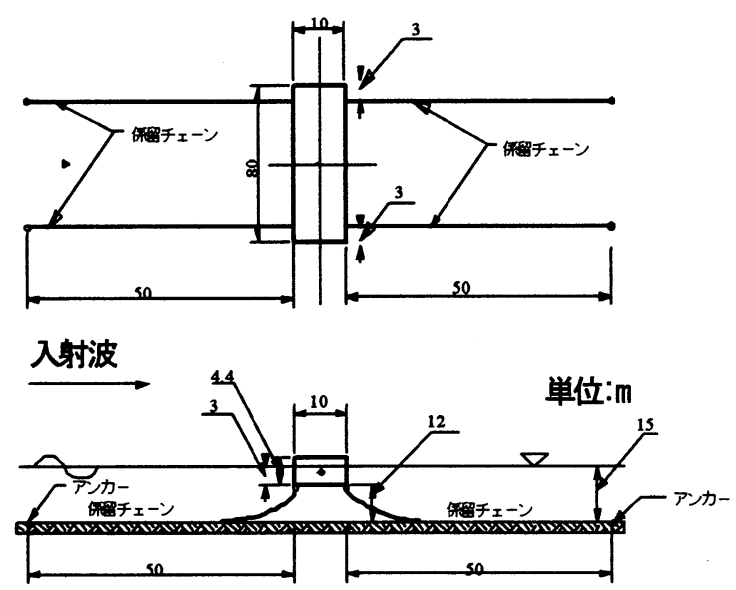

図ー 3 ポンツーン形式の浮防波堤
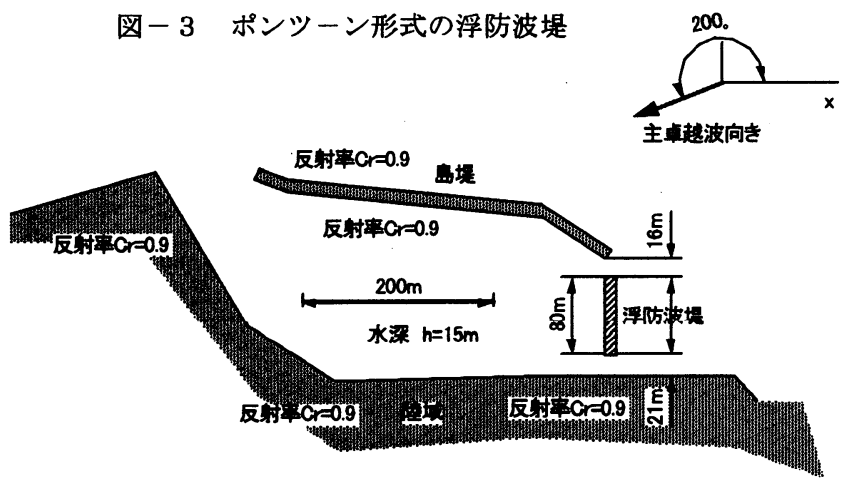

図-4 浮防波堤を含む港湾域の算定モデル

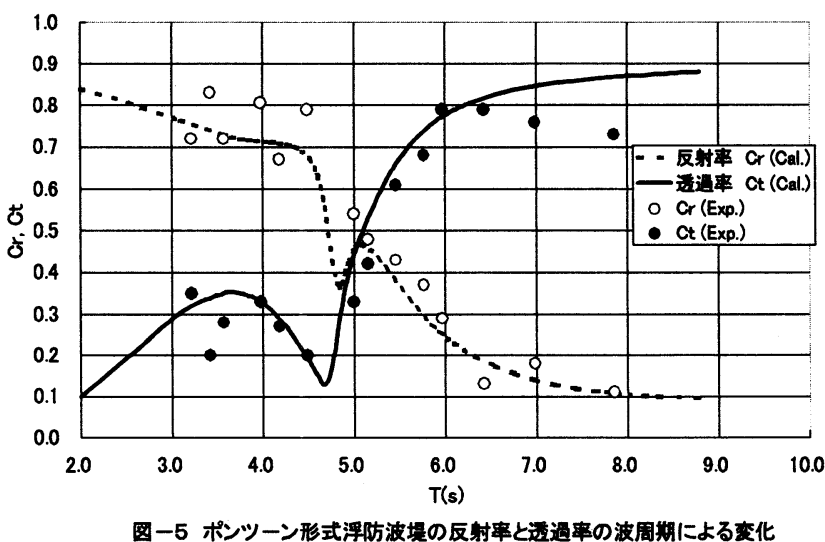

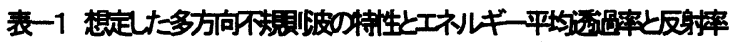

\begin{tabular}{|c|c|c|c|c|c|c|c|}
\hline$T 1 / 3$ & $\mathrm{HI} / 3$ & 主波亩芑 & Simax & 周期分空 & 方向分㶾 & ${ }^{2}$ & $O_{p}$ \\
\hline $4.6 \mathrm{~s}$ & $1 \mathrm{~m}$ & $200^{\circ}$ & 10 & 5 & 7 & 0.42 & 0.63 \\
\hline $6 s$ & $1 \mathrm{~m}$ & $200^{\circ}$ & 10 & 5 & 7 & 0.65 & 0.45 \\
\hline
\end{tabular}

よる算定結果の両者を現地スケールに換算して, 作用波 の周期による変化で示す.この図より，透過・反射率は， 波周期Tにより有意に変化することや，このため不規則 波を対象とするとき透過・反射率をどのように与えるべ きかが問題になることが分かる.

\section{（３）港湾域の波高分布}

以下で紹介する算定結果は，表一 1 に示す特性をもつ 多方向不規則波を作用させたときの結果である．表中で $\mathrm{Tl} / 3, \mathrm{Hl} / 3$ はそれぞれ有義波の周期, 波高を, $S_{\max }$ は方 向集中度パラメータを示す。

まず最初に，図一 4 の港湾において浮防波堤を取り除 いたときの波高分布の算定結果 $(\mathrm{Tl} / 3=4.6 \mathrm{~s})$ を図一 6 に示寸.この図より，浮防波堤がないときには，港湾内 において入射波高と同程度の波高值が見られ，何らかの 防波施設の必要性が確認できる.また, 図一7は, 浮防 波堤の透過率を 0.99 , 反射率を 0 とほぼ浮防波堤がない 状態と同一の条件にしたときの結果(T1/3=4.6s) を示す. このときの浮防波堤まわりの波高分布は, 図一6のそれ がないときの波高分布とほぼ同じであり，算定における 透過堤の取り扱いの妥当性が碓認できる.

次に, 図一 8，9，10は，T1/3=4.6sのときについ て，透過・反射率を(1)個々の代表成分波に対して与える 場合，(2)有義波周期を代表量として，それに対して与え る場合, (3)表一 1 中に示すエネルギー平均量で与える場 合の 3 者の算定結果を示寸.これらの図の比較から，上 記の(1)と(3)に対応する結果はほぼ同程度の波高值を示す のに対して，(2)の方法による結果では，港内で 1 割程度 波高值が低いなどの差異が見られる．これは，図一5に 見られるように, 有義波周期に対応する周期条件下で透 過率が極小となり，この透過率を代表值として用いて算 定しているためである.

そして，不規則波を対象とするときには，上記のゆか 


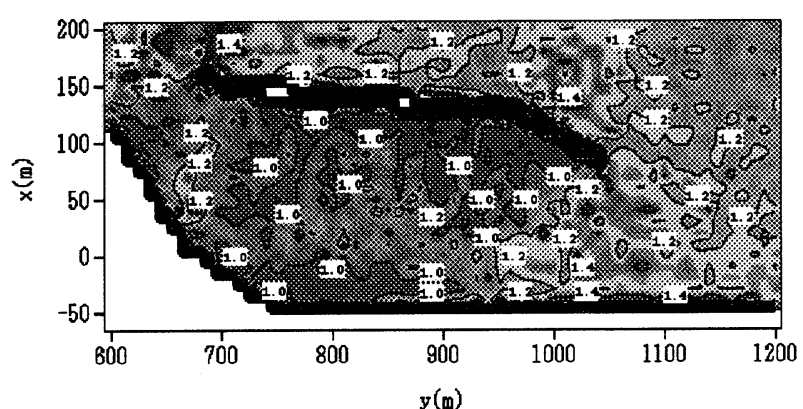

図一 6 浮防波堤のないとき $(\mathrm{T} 1 / 3=4.6 \mathrm{~s})$

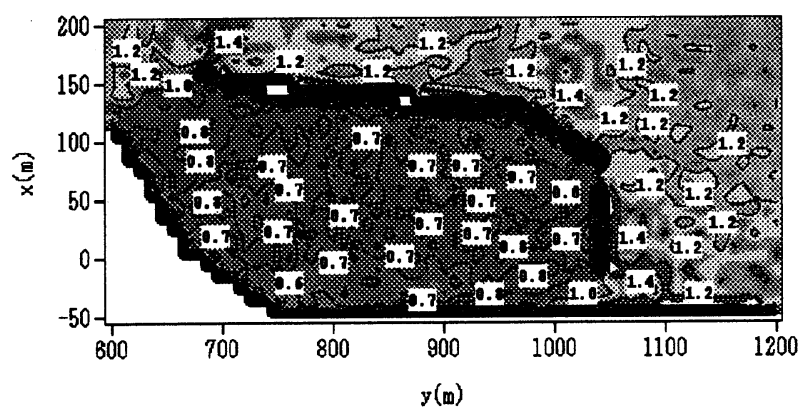

図－8 CrとCtの周期変化を考虑したとき $(\mathrm{T} 1 / 3=4.6 \mathrm{~s})$

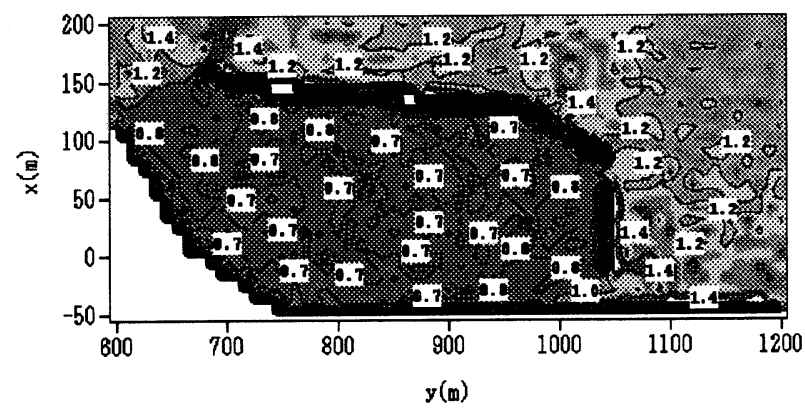

図ー10 パワー平均のCrとCtを用いたとき (T1/3=4.6s)

(3のように透過・反射率の周期特性の影響を何らかの方 法で考慮した算定が望ましいといえる。

本研究では, $\mathrm{T} 1 / 3=6 \mathbf{s}$ のきについても, 上記(1)〜(3) の方法により算定を行い，同様の検討を進めているが， このときには, 逆に(1)の方法による結果が，(2)のそれに 比較して, 約 1 割程度低く現れることなどを確認してお り,これはやはり図一 5 に示寸透過率の周期変化による 影響と考えられる。

\section{4. 結語}

従来よりの有義波など代表波に対する一定の透過・反 射率を用いる方法は, 透過堤の特性を十分に表すことが

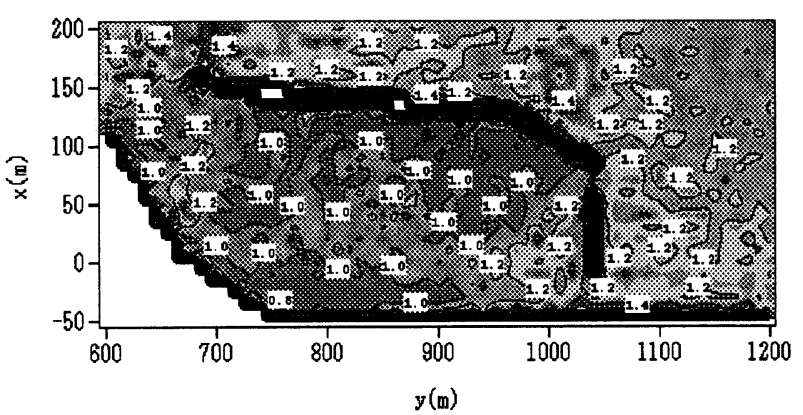

図 -7 浮防波堤のCt=0.99, $\mathrm{Cr}=0.0$ のとき $(\mathrm{T} 1 / 3=4.6 \mathrm{~s})$

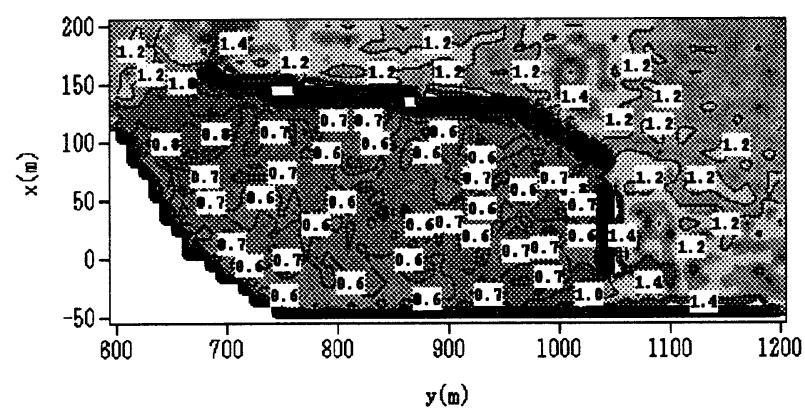

図一9 有義波に対する一定のCrとCtを用いたとき (T1/3=4.6s)

できず，波高分布を過大評価あるいは過小評価する恐れ があり，透過・反射率の周期特性を考慮した算定が望ま しい.

そして，周期特性を考慮する方法としては，不規則波 を構成する各周期成分波の個々に対して透過・反射率を 設定するか，あるいは周波数スペクトルを対象にして定 義されるエネルギー平均的な透過・反射率を設定する 方法を用いると, 合理的な港内静穏度の評価が可能に なる。

\section{参考文献}

1)合田良実 : 港湾構造物の耐波設計法, 鹿島出版会, pp.31-80, 1977.

2)中村孝幸・佐伯信哉 : 透過堤を含む港湾域の波高分 布の算定法に関する研究, 海洋開発論文集, 第15巻, pp.339-344,1999.

3) Isaacson, M. Q. :Vertical cylinder of arbitrary section in waves, Jour. of Waterways, Coastal and Ocean Eng. Div., ASCE, Vol.104, No.ww4, pp.309-322, 1978.

4)中村 孝幸・大森 禎敏 : 浮栈橋を含む港湾域の波高 分布の算定法に関する研究, 海岸工学論文集, 第41巻, pp.971-975, 1994. 